Advances in Hearing Rehabilitation 


\section{Advances in Oto-Rhino-Laryngology}

Vol. 81

Series Editor

Patrick J. Bradley Nottingham 


\section{Advances in Hearing Rehabilitation}

Volume Editors

Simon K.W. Lloyd Manchester

Neil P. Donnelly Cambridge

46 figures, 23 in color, and 10 tables, 2018 
Simon K.W. Lloyd

Honorary Clinical Professor of Otolaryngology and

Consultant Otologist

University Department of Otolaryngology Head and

Neck Surgery

Peter Mount House

Manchester Royal Infirmary

Manchester M13 9WL (UK)
Neil P. Donnelly

Consultant Otoneurological and Skull Base Surgeon

Department of Otolaryngology

Cambridge University Hospitals NHS Foundation Trust

Cambridge CB2 2QQ (UK)

Library of Congress Cataloging-in-Publication Data

Names: Lloyd, Simon (Simon Kingsley Wickham), editor. | Donnelly, Neil, 1972-

editor.

Title: Advances in hearing rehabilitation / volume editors, Simon K.W. Lloyd,

Neil Donnelly.

Other titles: Advances in oto-rhino-laryngology ; v. 81. 0065-3071

Description: Basel ; New York : Karger, 2018. | Series: Advances in

oto-rhino-laryngology, ISSN 0065-3071; vol. 81 | Includes bibliographical

references and indexes.

Identifiers: LCCN 2018004767| ISBN 9783318063141 (hard cover : alk. paper) |

ISBN 9783318063158 (electronic version)

Subjects: | MESH: Cochlear Implantation | Correction of Hearing Impairment |

Ear Diseases--rehabilitation | Ear, Middle--pathology

Classification: LCC RF300 | NLM WV 274 | DDC 617.8/9--dc23 LC record available at

https://lccn.loc.gov/2018004767

Bibliographic Indices. This publication is listed in bibliographic services, including Current Contents ${ }^{\circledR}$ and Index Medicus.

Disclaimer. The statements, opinions and data contained in this publication are solely those of the individual authors and contributors and not of the publisher and the editor(s). The appearance of advertisements in the book is not a warranty, endorsement, or approval of the products or services advertised or of their effectiveness, quality or safety. The publisher and the editor(s) disclaim responsibility for any injury to persons or property resulting from any ideas, methods, instructions or products referred to in the content or advertisements.

Drug Dosage. The authors and the publisher have exerted every effort to ensure that drug selection and dosage set forth in this text are in accord with current recommendations and practice at the time of publication. However, in view of ongoing research, changes in government regulations, and the constant flow of information relating to drug therapy and drug reactions, the reader is urged to check the package insert for each drug for any change in indications and dosage and for added warnings and precautions. This is particularly important when the recommended agent is a new and/or infrequently employed drug.

All rights reserved. No part of this publication may be translated into other languages, reproduced or utilized in any form or by any means electronic or mechanical, including photocopying, recording, microcopying, or by any information storage and retrieval system, without permission in writing from the publisher.

(c) Copyright 2018 by S. Karger AG, P.O. Box, CH-4009 Basel (Switzerland)

www.karger.com

Printed on acid-free and non-aging paper (ISO 9706)

ISSN 0065-3071

e-ISSN 1662-2847

ISBN 978-3-318-06314-1

e-ISBN 978-3-318-06315-8 


\section{Contents}

VII Preface

Lloyd, S.K.W. (Manchester); Donnelly, N.P. (Cambridge)

1 New Imaging Modalities in Otology

Bance, M. (Cambridge); Zarowski, A. (Antwerp); Adamson, R.A. (Halifax, NS); Casselman, J.W. (Bruges)

14 Optimizing Ossicular Prosthesis Design and Placement

Bance, M. (Cambridge)

24 Advances in the Field of Bone Conduction Hearing Implants

McLeod, R.W.J.; Culling, J.F. (Cardiff); Jiang, D. (London)

32 Hearing Rehabilitation in Congenital Middle Ear Malformation

Frenzel, H. (Lübeck)

43 Hearing Rehabilitation with Active Middle Ear Implants

Donnelly, N.P. (Cambridge); Pennings, R.J.E. (Nijmegen)

57 Brain Plasticity and Rehabilitation with a Cochlear Implant

McKay, C.M. (Melbourne, VIC)

66 Hearing Preservation Cochlear Implant Surgery

Bruce, I.A. (Manchester); Todt, I. (Bielefeld)

74 Extended Applications for Cochlear Implantation

Hempel, J.M.; Simon, F.; Müller, J.M. (Munich)

81 Management of Cochlear Nerve Hypoplasia and Aplasia

Freeman, S.R. (Manchester); Sennaroglu, L. (Ankara)

93 Hearing Rehabilitation in Neurofibromatosis Type 2

North, H.J.D. (Sydney, NSW); Lloyd, S.K.W. (Manchester)

105 The Future of Cochlear Implant Design

Mitchell-Innes, A. (Birmingham); Saeed, S.R. (London); Irving, R. (Birmingham)

114 Pharmacological Issues in Hearing Rehabilitation

Bird, P.A.; Bergin, M.J. (Christchurch)

123 Intraoperative Auditory System Monitoring

Miyazaki, H. (Tokyo); Caye-Thomasen, P. (Copenhagen) 
133 Diagnosis and Treatment of Perilymphatic Fistula

Deveze, A. (Marseille); Matsuda, H. (Moroyamamachi); Elziere, M. (Marseille);

Ikezono, T. (Moroyamamachi)

146 The Role of the Eustachian Tube in Middle Ear Disease

Tysome, J.R. (Cambridge); Sudhoff, H. (Bielefeld)

153 Author Index

154 Subject Index 


\section{Preface}

According to the World Health Organization, hearing loss ranks seventh as a cause for disease burden with 26 million years of healthy life lost globally each year. There is estimated to be 630 million people worldwide affected by some kind of hearing loss. On an individual level, the effect of hearing loss was eloquently summed up by Helen Keller, a remarkable American woman who lived around the turn of the 20th century and dedicated her life to social reform. She was rendered both blind and deaf at the age of 19 months following Scarlett fever and described blindness as separating people from things but deafness as separating people from people. Thus, hearing loss is an important cause of social isolation with both psychological and economic implications.

In the early 21 st century, we are incredibly fortunate to be able to offer effective hearing rehabilitation to most patients with hearing loss, a situation unique among sensory losses. There has been a progressive improvement in hearing aid technologies, and surgical reconstruction of conductive hearing losses has become increasingly reliable with improvements in surgical technique and prosthesis design. The most dynamic area of development in the field of hearing rehabilitation is, however, implantation otology. Cochlear implants have been in mainstream clinical use for 30 years and have revolutionized the lives of those with acquired and congenital profound sensorineural hearing loss. Implantable hearing aids have proliferated over the past 15 years and now fill the gap between hearing aids and cochlear implants as well as offering an alternative means of rehabilitation for those that cannot wear traditional hearing aids. For those that do not have a functional cochlear nerve or have a cochlea that is absent or significantly deformed, auditory brainstem implantation now has a proven track record in offering limited access to hearing.

This book brings together some of the world's leading experts in hearing restoration to discuss recent advances in all aspects of hearing implantation otology. Chapters review the evidence behind the current applications of the wide range of hearing implants available for different types of hearing loss. The focus is on who should be implanted, with which device and how the outcomes can be optimized. There are contributions from authors leading in the extended applications of implantation otology and those horizon spotting for the next developments within this exciting field. New imaging techniques for the middle and inner ear are explored as well as innovations to improve Eustachian tube function.

We are very grateful to all the contributors for the enormous effort put into producing this book. It is aimed at otolaryngologists, audiologists and hearing rehabilitation professionals, and we very much hopeful that it will be a useful resource in providing a detailed overview of the current stateof-the-art in hearing rehabilitation.

Simon K.W. Lloyd, Manchester Neil P. Donnelly, Cambridge 
